\title{
Impact of Smart City on Social Relations
}

\author{
Vidya Dhere, Ujwala Bendale
}

\begin{abstract}
Smart city has been recently evolved concept that focuses upon economic development of society. The human civilization has revolved around technological development. Mankind has always tried to curb nature for their own convenient living through development in techniques of means of production and mode of production. With the advent of every new technology a new social relations has evolved giving rise to new social environment. Equal importance has to be given to material development and social environment that is likely to emerged, particularly in modern society where technology has become inevitable for every social activity; human relations towards each other has been lost. Though technology is important for continent living, social relations are inevitable for happy living.

Index-Smart city, social relationship, technological development, material environment
\end{abstract}

\section{INTRODUCTION}

Aristrotal had rightly said," Man is a social animal". Living in a group is inevitable for human beings, not only for their needs to be fulfilled but for social support and emotional satisfaction. Exchange of ideas, sharing joy and sorrow is human nature. In order to communicate with each other, human being has developed various devices starting from gestures, language to modern means of communication. These developments in technology have helped human beings to increase their standard of living and lead a more convenient life. Technological development has caused various changes in society by changing the institutions, customs, laws, and different forms of organizations. Ogburn has said, "Technology changes society by changing our environments to which we in turn adapt. This change is usually in the material environment and the adjustment we make with changes often modifies customs and social institutions." [1] The major fields where the technology takes place are production, communication and transportation that change all social relations. At hunting stage the relation between the members of society was very simple, intimate and primary level. These relations became more complex at agrarian society but remain simple, intimate and direct. When industrial revolution took place a new kind of society having non- agricultural occupational society took root. Further the technology developed with such a speed that the relations became complex, secondary, commercial, and indirect. Along with changes in production, changes in communication and transportation also took place. The capturing of time and space was possible due to development in communication technology. The physical capturing of time and space was due to changes in transportation technology. The development of

Revised Manuscript Received on April 12, 2019.

Vidya Dhere, Assistant Professor, Bharati Vidyapeeth (Deemed to be) University, NEW Law College, Pune, India. (E-mail: namrata.dalvi68@gmail.com)

Ujwala Bendale, Assistant Professor, Bharati Vidyapeeth (Deemed to be) University, NEW Law College, Pune, India. (E-mail: dr.ujwalabendale@gmail.com) communication and transportation has encouraged international trade and interdependence of countries all over the world. We are considering world as one community or world citizenship. The development in technology has brought countries of the world under one roof. In the contemporary society the concept of 'smart city' has come up and taking momentum through government initiative in India.

\section{METHODOLOGY}

The methodology adopted in this research is purely doctrinal. The article is based upon various views express by scholars in their articles that are published online.

\section{FINDINGS}

Technological development has affected social relations to a greater extend. Human relations are becoming inhuman in nature. Social relations are evaluated in terms of money. Every relation like love, affection, friendship are evaluated with money as a measuring rode.

\section{RESULTS AND DISCUSSION}

The concept of smart city is introduced by Government of India in 2014 for the overall development of cities.[2] The word smart is interpreted as particular development in communication, transportation and technology at every walk of life in cities. There is no specific definition of smart city; each one will apply it as per their requirements. [3] The concept of smart city basically means providing maximum level of infrastructure to urban society by using ICT technology. Accordingly it includes adequate water and electricity supply, waste product management, public transportation, digitalization, e-governance, sustainable development, security to citizens particularly to children, women and senior citizens. [4] The main aim of smart city is advancement in quality of life of people through economic growth with the help of technological implementation. This will lead to better living conditions to citizens by availing various facilities at their door steps. The success of smart city plans will depend on active participation of the citizens in energy saving and implementation of new technology. [5]

Smart city project concentrates only on economic aspect the social aspect is altogether ignored or to what extend it will help the community to improve human relations is debatable.[6] The social legislations that are introduced by the government to curb the social menace talks high volumes about human relations in India. These social legislations like section 498A of Indian penal code to protect women from cruelty at the hands of husband and in-laws,

Blue Eyes Intelligence Engineering 
Senior citizens Act to protect old people, extra ,makes us think about the social relations which are the outcome of technological development. The materialistic attitude developed as a result of economic development has far reaching consequences on human relations starting from family life. It has led to disintegration of joint family; which was not only the production and consumption unit but has also served as social insurance unit. Joint family of course did not allowed individual liberty which has come in way of technological development, which gave rise to small nuclear family. This new modern family facilitated individual development of not only men but women also. Advanced means of communication and transportation facilitated migration from rural to urban and from joint to nuclear family. Availability of modern devices to fulfill needs made people think that they can live without any person in their life including family members. Children started adjusting in hostels without parents and parents adjusted in old age homes without children. This relation is justified on the ground that they are not emotional fools but more practical. The impact of family to control individual behavior has lessened. The dominant patriarchal family adopted democratic principles where each member of the family has freedom to express their views; women and children are also considered while taking important decisions. Father no more remains a dictator. There is greater social pressure relating achieved status, as well as there is no help from society at the time of family crisis. Expressing limitation of individual or family to other person is considered as weakness; people may take undue advantage of it. Modern family is compelled to rely on their own strength at the time of crisis. Money can solve all problems is a modern materialistic thinking of the people, accordingly less importance is given to human relations. Even today to a certain extend family satisfies physical and psychological needs of people. The desire to love and to be loved provides consolation against mental distress of complex social relationship.

Marital relations also underwent tremendous change; marriage is a contract and not sacrament. The concept of love and marriage has changed; love is a personal matter and marriage is a legal and social obligation. Privacy is important element in person's life; privacy has assumed importance more than relationship at all levels of life. People prefer to have love relations without marital ties. People overburden with career up gradation and the competitive nature of society, they cannot tolerate further obligation and responsibility of family. They go for live in relations that respect their privacy without any obligations of family members. The overburden of achieved status and lack of emotional satisfaction has not only affected social relations but also has affected emotional degradation resulting into physical unhealthiness.

The aim of smart city project is to improve the infrastructure and provide technology that will benefit people at all strata of society is of tremendous benefits to Indian population.[7] But at the same time such technology should not limit individual's ability and decline community life. Modern life has become mentally stressful, emotional instability and economic insecurity. One feels lonely in midst of crowd that surrounds them.
The State is over burden with responsibility of its citizens, where most of its responsibility was shared by joint family. Bureaucracy, which is the outcome of commercialized society, at state and private sector, has also affected working relations of people. Bureaucratic setup is has a distinguish characteristics of being technically specialized appointments, adherence to rules, objectivity of methods and emotional neutrality. These features of bureaucracy have added emotionless relation among the member of this setup.

\section{CONCLUSION}

There are many positive and negative aspects of smart city directly on human relations and indirectly on society. The focus of smart city should be on building infrastructure that will benefit people on both social and economic progress. Want of luxury should not affect human social and natural ecological environment of which they are part. It is thus our responsibility to discuss the issues of smart city and really be smart to implement that is beneficial for human living. The Government as well as people should study the effects of inventions and predict its probable consequences on social relationship. Thought technology is important it should be molded according to human needs with minimum negative aspect. It is not possible discard machines but it is possible with the help of human intelligence to see to it that it does harm those institution that foundation of human relationship. Before adopting any inventions caution should be taken and the consequences should be evaluated and accordingly implemented. All the parties involved in issues related to social and environmental development should come together to maintain a balance between environmental protection, sustainable development and social relations. [8]

\section{REFERENCES}

1. VIDYA BHUSHAN \& ASHA SACHDEVA, AN INTRODUCTION TO SOCIOLOGY, 2011.

2. Smart city concept by MoUD, Government of India, THE PLANNING TANK, (June. 26, 2019, 4:05 pm), https://planningtank.com/urbanisation/smart-cityconcept.html.

3. Smart city, THE CENTRE FOR CITIES, (June. 26, 2019, 2:20 p.m.) https://www.centreforcities.org/reader/smart-cities/whatis-a-smart-city/.

4. Ambili Mukundan, Smart City Mission In India And Its Impact On Real Estate, ADDA, (June. 26, 2019, 4:02 p.m.) http://adda.io/blog/2018/03/smart-city-mission-inindia-and-its-impact-on-real-estate/.

5. Anuj Puri, Smart Cities - A Futuristic Vision Of Urbanization In India, LINKEDIN, (July. 1, 2019, 4:08 p.m.), https://www.linkedin.com/pulse/20140826051804183425285-smart-cities-a-futuristic-vision-ofurbanization-in-india.

6. Impact of Smart Cities on India, THE PLANNING TANK, (June. 28, 2019, 2:38 pm), https://planningtank.com/city-insight/impact-smartcities-india. 
7. The impact of smart cities on Indian infrastructure, $\begin{array}{llll}\text { DAILYHUNT, (June. 29, 2019, 4:01 } & \text { 29, }\end{array}$ pm),https://m.dailyhunt.in/news/india/english/yourstoryepaper yourstory/the+impact+of+smart+cities+on+indian+infras tructure-newsid-87122667.

8. Sarda, M., Deshpande, B., Dharm, J., Dhere, V., Different aspects of environmental laws , International Journal of Recent Technology and Engineering, 2019

9. Sarda, M., Deshpande, B., Deo, S., Karanjkar, A comparative study on Maslow's theory and Indian Ashrama system, International Journal of Innovative Technology and Exploring Engineering ,2018

10. Sarda, M., Deshpande, B., Shringarpure, S., Smart city Use of technology and the needed labor reforms, International Journal of Innovative Technology and Exploring Engineering ,2018 